\title{
The Role of Islamic Work Ethics to Entrepreneurial Intention: The Study of Undergraduate Students in Indonesia
}

\author{
Gusti Oka Widana ${ }^{1}$, Nurwati ${ }^{2}$ \\ \{okawidana@itb-ad.ac.id ${ }^{1}$ \} \\ Institut Teknologi dan Bisnis Ahmad Dahlan, Indonesia ${ }^{1,2}$
}

\begin{abstract}
Entrepreneurs is important bringing advancements of a country's economy, yet entrepreneurs are created not born. Previous researches acknowledged that entrepreneurship activities were intentional based and having strong relationship with individual's values or culture. As for Moslem, the inherent individual culture, is in form of Islamic Work Ethics, which should support entrepreneurship. This objective of this study is to reveal the role of Islamic Work Ethics in influencing entrepreneurial intention of Indonesian under graduate students. The study is much relevant, since the students are the candidates of entrepreneurs in the future. Upon using Structural Equation Modelling, the study finds strong relationship between all variables. The discussion of finding, as well as future research direction is provided.
\end{abstract}

Keywords: Entrepreneurial Intention, Islamic Work Ethics, Academic Performance, Theory of Planned Behavior.

\section{Introduction}

Entrepreneurs have significant role in creating growth and giving advancements to a country's economy as Baron \& Shane [1], called the as "engines of economic growth". The entrepreneurs are actually made and not born [2], meaning entrepreneurs can be trained. Therefore, it is important to look at the factors that make someone into entrepreneurship and the issues related to the development of entrepreneurs [3]. As many empirical studies have shown result that entrepreneurship activities have been intentional based. The entrepreneurs started with some extent of entrepreneurial intention before they turned out to become ones. People will not become an entrepreneur without certain triggers, or having an intention [4].

Many researches also identified the connection between underlying values to Entrepreneurial Intentions ("EI"). The values of individual will determine entrepreneurial intentions [5][6]. Many evidence supported the view that aspiring entrepreneurs had certain values and interests regarding entrepreneurship [7]. Bird [8] argued that the entrepreneur's personal needs, values, and beliefs was the foundations of the intentional process toward entrepreneurial activity.

Particularly for Muslim (the followers of Islam), become entrepreneur is encouraged. Entrepreneurial characteristics are founded on principles stated in the Quran and Hadith to guide entrepreneurial operations [9]. Thus, Islam can be regarded as an "entrepreneurial religion" [10][11] in the sense that it enables and promotes entrepreneurial activity, i.e., opportunity pursuit, risk-taking and innovation. As also being shown by the Prophet Muhammad and his 
companions, entrepreneurship is original part of the Islamic culture [12]. The presence of the Islamic culture in the business or entrepreneurship environment is called as Islamic Work (IWE). IWE is also an attitude towards work as a virtue in human's lives [13].

As it has theoretical support, that IWE should be able to emerge EI, yet the relevant research is rare. It becomes mostly important to understand how IWE can emerge the intention for entrepreneurship, particularly among students who are the future entrepreneur. This becomes the objective of this study.

Relevant with the context of Indonesia as the largest Muslim country in the world, entrepreneurship is underdeveloped. According to Global Entrepreneurship Index 2016 (http://www.gemconsortium.org/country-profile/70), Indonesian entrepreneurial intention is ranked 25 (of 65 countries), and motivation for entrepreneurship is ranked 34 (of 65 countries). The Indonesia's position is behind the neighbor countries i.e. Singapore, Malaysia and Thailand.

\section{Research Method}

\subsection{Hypotheses Development}

\subsubsection{The Theory of Planned Behavior and Entrepreneurial Intention}

Theory of planned behavior (TPB) was developed in 1991 by Ajzen [14], which was actually as an extension to Theory of Reasoned Action [15]. Behavior is not performed mindlessly but follows reasonably and consistently from the behavior-relevant information and behavior reinforced by rewarding events and weakened by pushing events, which consisting three antecedents i.e. (i) Attitude Behavior (ATB); (ii) Subjective Norm (SUN) and; (iii) Perceived Behavioral Control (PBC) [14]. TPB can be applied specifically in understanding specific behaviors, such as purchasing behaviors, drinking behavior etc. Many research shows that TPB can be an effective and influential model for studying and understanding EI [16][17][18].

EI was defined as willingness of individuals to perform entrepreneurial behavior, to engage in entrepreneurial action, to be self- employed, or to establish new business [19][20][21]. The intention represents the motivation and conscious effort of an individual to decide [22]. Boulton \& Turner [2] added that becoming an entrepreneur was not a fate but a decision made by individuals. People still would have intention and determination to become entrepreneur, despite the difficulties that they may face, for example uncertainties, barriers and financial risks [23].

The entrepreneurship process is a strategically planned sequence of activities encompassing opportunity identification, evaluation, and execution [24], where intention is a fundamental requirement for reasoned action [14][15].

\subsubsection{Entrepreneurship in Islam and Islamic Work Ethics}

Entrepreneurship is the process by which an individual pursues opportunities regardless to the access to the resources this individual has [25]. Ali \& al-Owaihan [12], Ghoul [26], Ramadani et al. [27] and Vargas-Hernández, Noruzi \& Sariolghalam [28] saw that entrepreneurship was inherent within Islamic culture, thereby Muslims were encouraged become entrepreneurs. Entrepreneurial characteristics are founded on principles stated in the Quran and Hadist [9]. Based on Quran, Islam supports a free-trade, and profit is legitimate if it is incompliance with Islamic ethics, e.g. not exploits others [29]. For Muslims, economy is as a 
tool for spiritual purposes, where prosperity means a good life and help others [30]. Thus, Islam can be regarded as an "entrepreneurial religion" [10][11] in the sense that it enables and promotes entrepreneurial activity, i.e., opportunity pursuit, risk-taking and innovation. The presence of the Islamic culture in the business or entrepreneurship environment is called as Islamic Work (IWE). IWE is also an attitude towards work as a virtue in human's lives [13]. Work is considered a source of independence and a means to encourage personal growth, selfesteem, satisfaction, and self-fulfillment [29].

There is different concept between works ethics as being viewed by western civilization and IWE. In general, work ethic is the central work processes, which outcome are in from of job satisfaction, motivation, organizational commitment and work performance [31][32]. Work ethics is defined as "the bundle of values, beliefs, intentions, and objectives that people bring to their work and the conditions in which they do it" [33]. According to Ali, from the point of view western society, the concept of works had evolved which previously were sinful and a burden, to become a productive activity essential for serving God. However, the its basic goal remains the same, which is to gain money. On the contrary, in Islam, hard work is not enough, but works must lead to the enhancement of the well-being, as individuals and society [34].

IWE is defined as “... an obligatory activity and a virtue in light of the needs of man [person] and a necessity to establish equilibrium in one's individual and social life. Work enables man [person] to be independent and is a source of self-respect, satisfaction, and fulfilment. Success and progress on the job depends on hard work and commitment to one's job. Commitment to work also involves a desire to improve the community and societal welfare. Society would have fewer problems if each person were committed to his work and avoided unethical methods of wealth accumulation. Creative work and cooperation are not only sources of happiness but are considered noble deeds, as well" [34].

\subsubsection{Islamic Work Ethics and Entrepreneurial Intention}

Some research have proposed that individuals' values will determine EI [5][6]. This view was supported by evidence, e.g. that a lot of successful entrepreneurs have certain values and interest regarding entrepreneurship which then enhance the potential drive of EI [7]. Bird [8] explained that needs, values, and beliefs of an individual is as the foundations of the intentional process toward entrepreneurial activity.

Previous research also has shown that some reasons can be as background of the intention of individuals, which amongst other factors, religion was considered as a core factor. Religion influences the attitude, values, behaviors of an individual and communities [35][36]; their way of life [9], and their decision to become entrepreneurs or select their jobs. Thereto, individual's values will determine EI [5][6]. Evidence support the view that most successful entrepreneurs have certain values and interests regarding entrepreneurship [7]. Bird [8] agrees that the entrepreneur's personal needs, values, and beliefs was the foundations of the intentional process toward entrepreneurial activity.

As Islam support entrepreneurship, so Islamic Work Ethics should also encourage Entrepreneurial Intention. In Islam, the intention, is important, as prophet Muhammad (pbuh) has said "The reward of deeds depends upon the intention and every person will get the reward according to what he has intended...." [Sahih al-Bukhari, Volume 1, Book 1, Hadist number 1]. This is aligned with Quran: "Whoever works righteousness, man or woman, and has Faith, verily, to him will We give a new Life, a life that is good and pure and We will bestow on such their reward according to the best of their actions." [Quran: 16:97]. 
As TPB consist of 3 (three) variables i.e. (i) Attitude Behaviour (ATB); (ii) Subjective Norm (SUN) and; (iii) Perceived Behavioral Control (PBC), then this study propose hypothesis as follow:

$\mathrm{H} 1$ : There is relationship between Islamic Work Ethics (IWE) and Attitude Behavior (ATB)

$\mathrm{H} 2$ : There is relationship between Islamic Work Ethics (IWE) and Subjective Norm (SUN)

$\mathrm{H} 3$ : There is relationship between Islamic Work Ethics (IWE) and Perceived Control Behavior (PCB)

$\mathrm{H} 4$ : There is relationship between Attitude Behavior (ATB) and Entrepreneurial Intention (ENI)

H5 : There is relationship between Subjective Norm (SUN) and Entrepreneurial Intention (ENI)

H6 : There is relationship between Perceived Control Behavior (PCB) and Entrepreneurial Intention (ENI)

$\mathrm{H} 7$ : There is relationship between Islamic Work Ethics (IWE) and Entrepreneurial Intention (ENI)

The study also identifies some indirect relationship, whereby some variables become mediating variables. The hypothesis is:

H8 : Attitude Behavior (ATB) is mediating variable for the relationship between Islamic Work Ethics (IWE) and Entrepreneurial Intention (ENI)

H9 : Subjective Norms (SUN) is mediating variable for the relationship between Islamic Work Ethics (IWE) and Entrepreneurial Intention (ENI)

H10: Perceived Behavioral Control (PBC) is mediating variable for the relationship between Islamic Work Ethics (IWE) and Entrepreneurial Intention (ENI).

Thereby, the conceptual model of this study, can be drawn as follow:

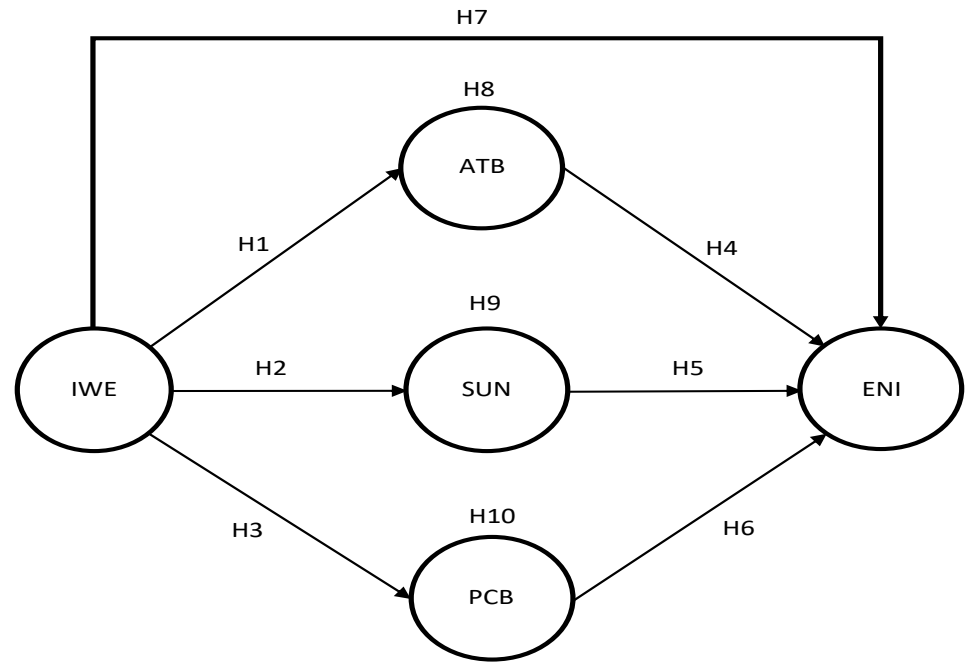

Picture 1. The Conceptual Model 


\subsection{Research Methodology}

\subsubsection{Research and sampling design}

This study uses a quantitative approach, as it is among other time saving and cost effective. The target population is undergraduate students from universities in Jakarta, Indonesia. Since it is difficult to obtain comprehensive sampling frame, this study uses the convenience sampling method. The final sample is composed of 150 students, which is acceptable for SEM [37][38]. An analysis of the demographic profile of respondents shows that the majority of the students $(64 \% ; n=96)$ are female. In terms of age, there were more respondents between 22 and 23 years of age $(33 \% ; \mathrm{N}=50)$, between $23-24$ years of age $30 \%(\mathrm{n}=40)$, followed by those who are 21 years and younger $(25 \% ; n=37)$, and those whose are 25 years and above $15 \%(n=23)$.

\subsubsection{Data collection and analysis}

This research uses self-administered questionnaire, sent to 170 respondents in the period of June to Auguts 2019. At the end, totally 150 respondents have filled fully and sent back the questionnaire. The instrument used by this study was adapted from previous studies. For IWE is adapted from Rokhman [39] and regarding TPB is adapted from Autio et. al [40]. All original instruments were firstly developed in English. In order increase the comprehension of the respondents, the original instruments are translated into Bahasa Indonesia (Indonesian language), follow the procedure set by Forsyth et al. [41]. The instrument use 5 (five) scales of Linkert.

Data are analyzed using SPSS version 22.0 and AMOS version 22. Descriptive statistics are used for analyzing the demographic profile of respondents. Following recommendation from Anderson \& Gerbing [37], two stages data analysis is conducted. Firstly, using confirmatory factor analysis (CFA) to assess the measurement models, then followed by simultaneous assessment of the measurement and structural models

\section{Findings and Discussion}

\subsection{Assessment of Measurement Model}

The test of validity and reliability is conducted. Using Amos version 22, to perform Confirmatory Factor Analysis, it is found that loading factor of all instruments is more than 0,5. It is also found that construct reliability is larger than 0,7 and the average variance extracted $(A V E)$ is more than 0,5 . Thus, as according to Ghozali [38], all instrument can be regarded as valid and reliable.

\subsection{Assessment of structural model}

Maximum likelihood estimation has been satisfied with the fulfilment some assumption. In regards with sample size, this study is used 150 respondents, which is acceptable for SEM [37][38]. The data is regarded as normal distribution since critical ratio (CR) for the kurtosis and skewness lay within $-2,58$ to $+2,58$. In addition for multivariate outliers, using criterion for Mahalanobis Distance, no data can be identified as outliers. For degrees of freedom (DF), the 
model is categorized since the value of DF is 457 . Lastly the goodness of fit of the model being used by this study is considered fit, as shown on table 1 .

Table 1. Goodness of Fit Index of the Model

\begin{tabular}{|c|c|c|c|}
\hline Goodness of fit index & Cut-off value & Research Model & Assessment \\
\hline Significant probability & $\geq 0.05$ & 0,000 & Marginal \\
\hline RMSEA & $\leq 0.08$ & 0,057 & Fit \\
\hline GFI & $\geq 0.90$ & 0,784 & Marginal \\
\hline AGFI & $\geq 0.90$ & 0,751 & Marginal \\
\hline CMIN/DF & $\leq 2.0$ & 1,490 & Fit \\
\hline TLI & $\geq 0.90$ & 0,940 & Fit \\
\hline CFI & $\geq 0.90$ & 0,945 & Fit \\
\hline
\end{tabular}

The full model of this study is as follow:

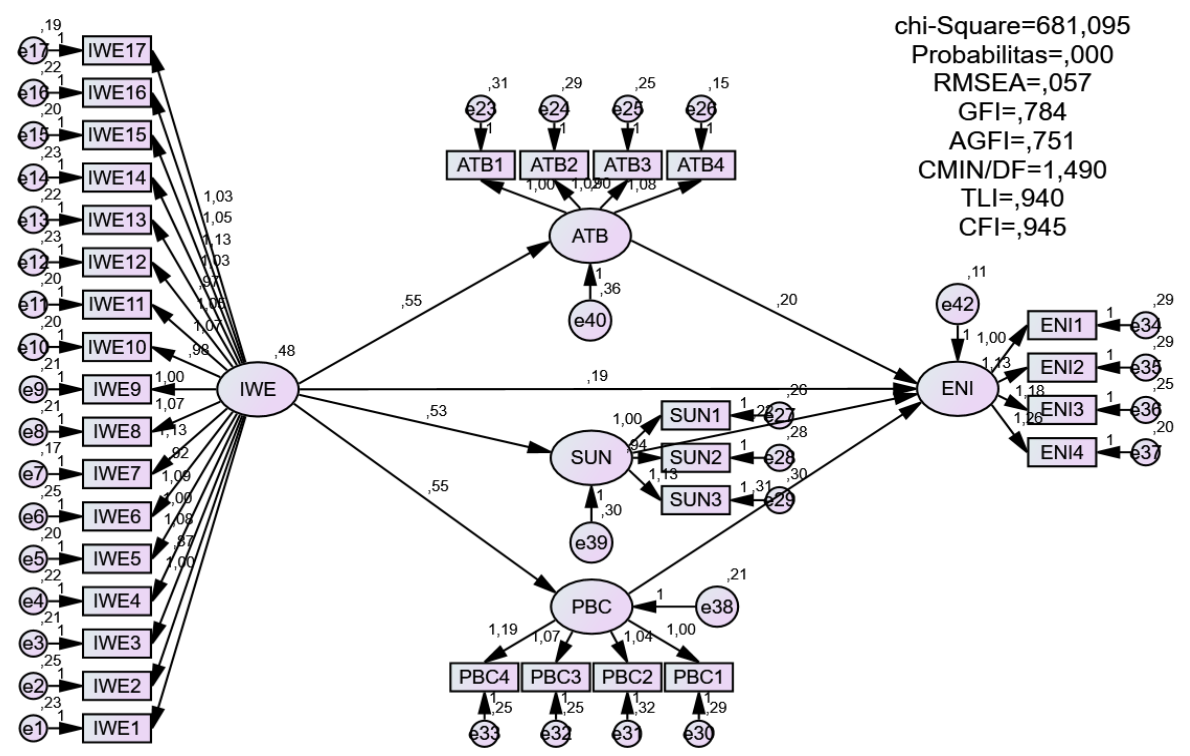

Picture 2. The Full Model as output of AMOS 22.

The result of test of hypothesis $\mathrm{H} 1$ to $\mathrm{H} 7<$ which test direct relationship of two variables, is as follow:

Table 2. Hypothesis Assessment - Direct Relationship

\begin{tabular}{|c|c|c|c|c|c|c|}
\hline Hypothesis & Path & Estimate & S.E. & C.R. & P & Assessment \\
\hline H1 & ATB <--- IWE & .553 & .091 & 6.072 & $0.000^{* * *}$ & Accepted \\
\hline H2 & SUN <--- IWE & .528 & .088 & 6.032 & $0.000^{* * *}$ & Accepted \\
\hline H3 & PBC <--- IWE & .553 & .081 & 6.851 & $0.000^{* * *}$ & Accepted \\
\hline H4 & ENI <--- ATB & .199 & .077 & 2.595 & $0.009^{* *}$ & Accepted \\
\hline H5 & ENI <--- SUN & .218 & .085 & 2.546 & $0.011^{*}$ & Accepted \\
\hline
\end{tabular}




\begin{tabular}{|c|c|c|c|c|c|c|}
\hline Hypothesis & Path & Estimate & S.E. & C.R. & P & Assessment \\
\hline H6 & ENI <--- PBC & .311 & .109 & 2.853 & $0.004^{* *}$ & Accepted \\
\hline H7 & ENI <--- IWE & .187 & .072 & 2.597 & $0.009^{* *}$ & Accepted \\
\hline
\end{tabular}

Note: ${ }^{*} \mathrm{p}<0.05 ; * * \mathrm{p}<0.01 ; * * * \mathrm{p}<0.001$.

H8 to $\mathrm{H} 10$ are hypotheses with one variable as mediator between two variables.

Table 3. Hypothesis Assessment - Indirect Relationship

\begin{tabular}{|c|c|c|c|}
\hline Hypothesis & Path & Sobel Statistic & \\
\hline H8 & ENI $<-$-ATB $<---$ IWE & 2.351466 & Accepted \\
\hline H9 & ENI $<-$-SUN $<---$ IWE & 2,331076 & Accepted \\
\hline H10 & ENI <--SUN <--- IWE & 2,608842 & Accepted \\
\hline
\end{tabular}

Note: ${ }^{*} \mathrm{p}<0.05$.

\subsection{Discussion of Research Finding}

This study confirms that TPB can predict the EI, consistent with many previous studies [18][17][16][42].

The most significant contribution of this study is providing evidence regarding the role of IWE to drive all variable of TPB, i.e. PCB, SUN and ATB. As indicated by Hayton \& Cholakova [43], this study has shown there is a deep assumption underpinning intention, in this regard, IWE. Prabhu et al and Shinnar et al underline that mental prototypes will be needed on the formation of EI. Whereby, IWE has encouraged Muslims to see entrepreneurship as one way to carry out the teaching of their religion (Islam).

The prophet Muhammad (pbuh) once said "The best of people is those who benefit others" [al-Mu'jam al-Awsat, Hadist number 5937, grade Hasan] and “.... He should work with his hands so that he may benefit himself and give in charity." [Sahih Bukhari, Volume 8, Book 73, Number 51]. These two instructions give dimensions if IWE the linkage the linkage of IWE between the aspiration of individual and society, between work and prosperity, and between spirituality and ethical conduct. The value of work, however, lays on the persistently exploring new ways for discovering how create the happiness and prosperity of for the individual and the society. Those who engage in work are driven by a divine calling to serve people and to do what is good for the rest of the population explore and take advantage of.

IWE is not an absurd concept. Al-Aidaros, Shamsudin \& Idris [44] argue, IWE is moderates and yet realistic. IWE consider the capabilities of human as Allah knows the strength and weaknesses of human. It is not only religious morality in certain actions but cover the aspect of physical, spiritual, intellectual and emotional, individual and collective [45].

\section{Conclusion and Future Research Direction}

\subsection{Conclusion}

Scholars agree that entrepreneurs are made and intentional based. It has relationship with individual's values or culture. As for Moslem, the individual culture, is in form of Islamic Work Ethics (IWE), which should support entrepreneurship. 
While this study confirms the result of many previous studies that Theory of Planned Behavior can consistently predict the Entrepreneurial Intention (IE). The study also provide evidence regarding the role of IWE to drive all variable of TPB, i.e. Attitude Behavior (ATB), Subjective Norm (SU) and Perceived Control Behavior (PCB). This study has proved that there are underlying assumptions underpinning intentions thus IWE will be able to encourage Muslims to see entrepreneurship as one way to carry out the teaching of their religion (Islam).

\subsection{Future Research Direction}

This study is also support the recommendation of Fayolle and Linann [46] concerning the future research opportunity of Entrepreneurial Intention (IE), which among other look for the role of personal-level variables in the configuration of EI. In this regard, personal-level variables may consist of many variables and should be interacted among others. For example, IWE, as this study has given solid proved of its role, the next inquiry will be what the process needs to strengthen IWE.

\section{References}

[1] R. A. Baron, S. A. Shane, and A. Entrepreneurship 2nd, "a process perspective.” South-Western Cengage Learning, 2008.

[2] C. Boulton and P. Turner, Entrepreneurship in the Mastering Business in Asia Series. Singapore: John Wiley and Sons., 2005.

[3] H. A. Kadir, R. Masinaei, and N. Rahmani, "Long-Term Effects of Bank Consolidation Program in a Developing Economy," J. Asia Pacific Bus. Innov. Technol. Manag., vol. 1, no. 1, pp. 20 30, 2011.

[4] N. F. J. Krueger, M. D. Reilly, and A. L. Carsrud, "Competing Models of Entrepreneurial Intentions," J. Bus. Ventur., vol. 15, pp. 411-432., 2000.

[5] J. R. Hollenbeck and E. M. Whitener, "Reclaiming personality traits for personnel selection: Selfesteem as an illustrative case.," vol. 14, no. 1, pp. 181-191., 1988.

[6] I. Jaén and F. Liñán, "Work values in a changing economic environment: The role of entrepreneurial capital.," Int. J. Manpow., vol. 34, no. 8, pp. 939-960., 2013.

[7] S. H. Lee and P. K. Wong, "An exploratory study of technopreneurial intentions: A career anchor perspective," J. Bus. Ventur., vol. 19, no. 1, pp. 7-28., 2004.

[8] B. Bird, "Implementing entrepreneurial ideas: The case for intention," Acad. Manag. Rev., vol. 13, no. 3, pp. 442-453, 1988.

[9] M.-S. Oukil, "Entrepreneurship and entrepreneurs in an Islamic context," J. Islam. Hum. Adv. Res., vol. 3, no. 3, pp. 111-131, 2013.

[10] D. B. Audretsch, W. Boente, and J. P. Tamvada, "Religion and entrepreneurship," Vol, 2007.

[11] R. N. Kayed and M. K. Hassan, Islamic entrepreneurship. Routledge, 2013.

[12] A. J. Ali and A. Al-Owaihan, "Islamic work ethic: a critical review," Cross Cult. Manag. An Int. J., 2008.

[13] J. Debeljak, K. Krkač, and R. R. Rizk, "Back to basics: an Islamic perspective on business and work ethics," Soc. Responsib. J., 2008.

[14] I. Ajzen, "The theory of planned behavior," Organ. Behav. Hum. Decis. Process., vol. 50, no. 2, pp. 179-211, 1991.

[15] M. Fishbein and I. Ajzen, "Belief, attitude, intention, and behavior: An introduction to theory and research," 1977.

[16] J. A. Moriano, M. Gorgievski, M. Laguna, U. Stephan, and K. Zarafshani, "A cross-cultural approach to understanding entrepreneurial intention," J. Career Dev., vol. 39, no. 2, pp. 162-185, 2012.

[17] C. L. Shook and C. Bratianu, "Entrepreneurial intent in a transitional economy: an application of 
the theory of planned behavior to Romanian students," Int. Entrep. Manag. J., vol. 6, no. 3, pp. 231-247, 2010.

[18] M. Van Gelderen, M. Brand, M. Van Praag, W. Bodewes, E. Poutsma, and A. Van Gils, "Explaining entrepreneurial intentions by means of the theory of planned behaviour," Career Dev. Int., 2008.

[19] J. C. Carr and J. M. Sequeira, "Prior family business exposure as intergenerational influence and entrepreneurial intent: A theory of planned behavior approach," J. Bus. Res., vol. 60, no. 10, pp. 1090-1098, 2007.

[20] M. Dell, "An investigation of undergraduate student self-employment intention and the impact of entrepreneurship education and previous entrepreneurial experience," Dr. Philos. Sch. Bus. Univ. Aust., 2008.

[21] D. Dohse and S. G. Walter, "The role of entrepreneurship education and regional context in forming entrepreneurial intentions," Document de treball de l'IEB, 2010.

[22] M. Conner and C. J. Armitage, "Extending the theory of planned behavior: A review and avenues for further research," J. Appl. Soc. Psychol., vol. 28, no. 15, pp. 1429-1464, 1998.

[23] M. S. Keshari, "fundamentals of entrepreneurship-prentice hall of India raheem a.:(2006), 'role of shgs', yojana, vol. 50, no. 12." Renuka.

[24] S. Shane and S. Venkataraman, "The promise of entrepreneurship as a field of research," Acad. Manag. Rev., vol. 25, no. 1, pp. 217-226, 2000.

[25] B. R. Barringer and R. D. Ireland, "Successfully Launching New Ventures." Pearson Education, Inc., New Jersey, 2006.

[26] W. A. Ghoul, "Entrepreneurship within the framework of Shari'ah,” Int. J. Bus. Glob., vol. 15, no. 3, pp. 262-271, 2015.

[27] V. Ramadani, L.-P. Dana, S. Gërguri-Rashiti, and H. Abazi-Alili, "The profile of female entrepreneurs in the Republic of Macedonia," in Female Entrepreneurship in Transition Economies, Springer, 2015, pp. 159-180.

[28] J. G. Vargas-Hernández, M. R. Noruzi, and N. Sariolghalam, "An exploration of the affects of Islamic culture on entrepreneurial behaviors in Muslim countries," Asian Soc. Sci., vol. 6, no. 5, p. 120,2010

[29] D. A. Yousef, "Organizational commitment as a mediator of the relationship between Islamic work ethic and attitudes toward organizational change," Hum. Relations, vol. 53, no. 4, pp. 513$537,2000$.

[30] M. Kriger and Y. Seng, "Leadership with inner meaning: A contingency theory of leadership based on the worldviews of five religions," Leadersh. Q., vol. 16, no. 5, pp. 771-806, 2005.

[31] R. A. Roe and P. Ester, "Values and work: Empirical findings and theoretical perspective," Appl. Psychol., vol. 48, no. 1, pp. 1-21, 1999.

[32] D. Berings, F. De Fruyt, and R. Bouwen, "Work values and personality traits as predictors of enterprising and social vocational interests," Pers. Individ. Dif., vol. 36, no. 2, pp. 349-364, 2004.

[33] O. Clarke, "The work ethic: An international perspective," Work ethic-A Crit. Anal., pp. 121$150,1983$.

[34] A. Ali, "Scaling an Islamic work ethic," J. Soc. Psychol., vol. 128, no. 5, pp. 575-583, 1988.

[35] S. Mokhlis, "Relevancy and measurement of religiosity in consumer behavior research," Int. Bus. Res., vol. 2, no. 3, pp. 75-84, 2009.

[36] H. Khraim, "Measuring religiosity in consumer research from Islamic perspective," Int. J. Mark. Stud., vol. 2, no. 2, p. 166, 2010.

[37] J. C. Anderson and D. W. Gerbing, "Structural equation modeling in practice: A review and recommended two-step approach.," Psychol. Bull., vol. 103, no. 3, p. 411, 1988.

[38] I. Ghozali, "Model Persamaan St: Konsep Struktural Aplikasi dengan Amos 19.0." Semarang: BadanPenerbit UNDIP, 2011.

[39] W. Rokhman, "The effect of Islamic work ethics on work outcomes," EJBO-Electronic J. Bus. Ethics Organ. Stud., 2010.

[40] E. Autio, R. H. Keeley, M. Klofsten, G. GC Parker, and M. Hay, "Entrepreneurial intent among students in Scandinavia and in the USA," Enterp. Innov. Manag. Stud., vol. 2, no. 2, pp. 145-160, 
2001.

[41] B. H. Forsyth, M. S. Kudela, K. Levin, D. Lawrence, and G. B. Willis, "Methods for translating an English-language survey questionnaire on tobacco use into Mandarin, Cantonese, Korean, and Vietnamese," Field methods, vol. 19, no. 3, pp. 264-283, 2007.

[42] S. N. A. Ambad and D. H. D. A. Damit, "Determinants of entrepreneurial intention among undergraduate students in Malaysia," Procedia Econ. Financ., vol. 37, pp. 108-114, 2016.

[43] J. C. Hayton and M. Cholakova, "The role of affect in the creation and intentional pursuit of entrepreneurial ideas," Entrep. theory Pract., vol. 36, no. 1, pp. 41-67, 2012.

[44] A.-H. Al-Aidaros and F. Mohd Shamsudin, "Ethics and ethical theories from an Islamic perspective," Int. J. Islam. Thought, vol. 4, pp. 1-13, 2013.

[45] Yaken, What is the Meaning of My Belong to Islam? Beirut: Darul Al-Ressalh Publication, 2006.

[46] A. Fayolle and F. Liñán, "The future of research on entrepreneurial intentions," J. Bus. Res., vol. 67 , no. 5, pp. 663-666, 2014. 